\title{
The progesterone and protein composition of rabbit uterine flushings
}

\author{
Ruth E. Fowler, M. H. Johnson, ${ }^{*}$ D. E. Walters $\dagger$ and Hester P. M. Pratt \\ Department of Physiology, *Department of Anatomy, and $\dagger$ Department of Applied Biology, \\ Downing Street, Cambridge, U.K.
}

The protein profile of uterine secretions of many species changes characteristically in different reproductive states through the interplay of oestrogen and progesterone acting on uterine tissue. The most extensively studied uterine protein is uteroglobin (Beier, 1968; Krishnan \& Daniel, 1967), a protein of mol. wt 15,000 (Murray, McGaugey \& Yarus, 1972) secreted by the glandular epithelium of the uterus of the pregnant and pseudopregnant rabbit (Johnson, 1972), primarily as a result of stimulation by progesterone (Arthur \& Daniel, 1972; Rahman, Billiar \& Little, 1975). Although extensive analyses of the physico-chemical properties of uteroglobin have been undertaken, its functional role remains unclear. The protein has been shown to bind progesterone (Urzua, Stambaugh, Flickinger \& Mastroianni, 1970; Arthur, Cowan, \& Daniel 1972; Beato \& Baier, 1975), which has prompted the suggestion that it may act to carry the hormone between uterus and embryo. The potential importance of such a steroid-binding activity has been increased with the demonstrations that the preimplantation embryos of several species contain enzymes that may be involved in steroid biosyntheșis (Dickmann, Dey \& Gupta, 1975) and that the pig embryo is able to convert neutral steroid precursors and possibly progesterone to oestrogen in vitro (Perry, Heap, Burton \& Gadsby, 1976). These data have been taken as evidence that the conversion of maternal steroids to oestrogen by the embryo may constitute a critical phase in the process of implantation and the recognition of pregnancy in some species. An integral step in the process would be the transport of steroids through the hydrophilic media of uterine fluid and zona pellucida to and from the embryo. A qualitative transfer of radiolabelled progesterone from plasma to uterine flushing has been demonstrated previously in the guinea-pig (Challis \& Illingworth, 1970). We have, therefore, undertaken a preliminary investigation into the quantitative relationship between plasma progesterone, and progesterone and protein levels of uterine flushings in the pseudopregnant rabbit.

Pseudopregnancy was induced in young, mature female rabbits by injection of 100 i.u. HCG. One to 13 days after the HCG injection the rabbits were anaesthetized with sodium pentobarbitone (Nembutal: Abbott) and each uterine horn flushed in situ with 2 or $5 \mathrm{ml}$ cold, sterile saline. Flushings which were obviously contaminated with blood were discarded. The flushings were immediately centrifuged at $4^{\circ} \mathrm{C}$ to remove any cellular material present. An aliquot from each flushing was then removed for determination of total protein by the Lowry technique (Lowry, Rosebrough, Farr \& Randall, 1951) and for the proportion of uteroglobin as estimated from scans of acrylamide electrophoresis gels. A fraction of each $2 \mathrm{ml}$ uterine flushing was passed through a millipore filter (HAWP $02500,0.45 \mu \mathrm{m}$ ) precooled to $4^{\circ} \mathrm{C}$; the free progesterone is retained on the filter and the protein-bound progesterone passes through (Batra, 1974). The fractions recovered from this separation and the samples from horns flushed with $5 \mathrm{ml}$ saline were stored at $-20^{\circ} \mathrm{C}$ before analysis for steroids. Blood samples were also taken and centrifuged and the plasma stored similarly.

Progesterone, 17-hydroxyprogesterone and oestradiol-17 $\beta$ levels in plasma and uterine flushings were measured by radioimmunoassay methods described by Abraham, Hopper, Tulchinsky, Swerdloff \& Odell (1971). All steroids in the plasma and uterine flushings were extracted with ether. Steroids were then separated on Sephadex-LH20 columns prepared in benzene: methanol $(95: 5 \mathrm{v} / \mathrm{v})$. For separating oestrone from oestradiol-17ß, benzene: methanol mixtures of $85: 15(\mathrm{v} / \mathrm{v})$ were used (Emment \& Collins, 1972). The antisera, S-49-6 for progesterone and 17-hydroxyprogesterone, and S-52-5 for oestradiol-17ß, were kindly supplied by Dr G. E. Abraham. The S-49-6 antibody does not significantly cross-react with $20 \alpha$-dihydroprogesterone (Abraham et al., 1971) which is found in significant amounts in plasma during early pregnancy in the rabbit (Hilliard \& Eaton, 1971). No 
attempt was therefore made to measure this steroid in the present investigation. The separation of bound and free steroid in the radioimmunoassay was effected with dextran-coated charcoal. Triplicate measurements were used for the construction of standard curves. The sensitivity of the standard curve was 5-10 pg for oestradiol-17 $\beta$ and 10-25 pg for progesterone and 17-hydroxyprogesterone. The concentrations of steroid in duplicate samples of plasma and uterine flushings were calculated by interpolation from the standard curve which took the form of a non-linear asymptotic model which was fitted to the standard points by iterative methods (Walters, 1974). The between-assay variance was evaluated by duplicate measurements of the same sample in two different assays and the mean coefficient of variation of eight duplicate determinations was $11.4 \%$.

Table 1. Mean levels (range in parentheses) of progesterone and protein in uterine flushings and of progesterone in plasma of rabbits rendered pseudopregnant by injection of HCG (Day 0)

\begin{tabular}{|c|c|c|c|c|}
\hline $\begin{array}{c}\text { Day of pseudo- } \\
\text { pregnancy }\end{array}$ & $\begin{array}{l}\text { No. of } \\
\text { animals }\end{array}$ & $\begin{array}{c}\text { Protein } \\
\text { recovered/ } \\
\text { uterus (mg) }\end{array}$ & $\begin{array}{c}\text { Progesterone } \\
\text { recovered/ } \\
\text { uterus (ng) }\end{array}$ & $\begin{array}{c}\text { Plasma } \\
\text { progesterone } \\
(\mathrm{ng} / \mathrm{ml})\end{array}$ \\
\hline 0 & 3 & 0 & 0 & 0 \\
\hline 0.5 & 1 & $0 \cdot 2$ & $0 \cdot 2$ & 0.1 \\
\hline $1 \cdot 5$ & 1 & 1.0 & 0.9 & 1.8 \\
\hline $2 \cdot 5$ & 1 & $2 \cdot 4$ & $1 \cdot 0$ & $8 \cdot 0$ \\
\hline $3 \cdot 5$ & 1 & $10 \cdot 4$ & $27 \cdot 3$ & $14 \cdot 8$ \\
\hline $4 \cdot 5$ & 1 & $13 \cdot 0$ & $68 \cdot 0$ & $10 \cdot 6$ \\
\hline $5 \cdot 5$ & 4 & $6 \cdot 6(4 \cdot 1-12 \cdot 1)$ & $79 \cdot 1(41 \cdot 2-104 \cdot 8)$ & $7 \cdot 1(6 \cdot 3-10 \cdot 1)$ \\
\hline $6 \cdot 5$ & 3 & $4 \cdot 8(2 \cdot 2-7 \cdot 8)$ & $29 \cdot 8(11 \cdot 8-56 \cdot 5)$ & $24.5 \dagger$ \\
\hline $7 \cdot 5$ & 3 & $3.6(2.4-4.4)$ & $69 \cdot 1(66 \cdot 8-73 \cdot 4)$ & $22 \cdot 2(11 \cdot 5-38 \cdot 7)$ \\
\hline $8 \cdot 5$ & 1 & $7 \cdot 8$ & $53 \cdot 7$ & $8 \cdot 3$ \\
\hline $9 \cdot 5$ & 2 & $2 \cdot 1(1 \cdot 1-3 \cdot 0)$ & $29.4(24.0-34.8)$ & $29.0(17.6-40.4)$ \\
\hline $10 \cdot 5$ & 1 & 1.4 & $2 \cdot 6$ & $14 \cdot 0$ \\
\hline $11 \cdot 5$ & 1 & $1 \cdot 4$ & $2 \cdot 9$ & $27 \cdot 9$ \\
\hline $12 \cdot 5$ & 1 & 0.5 & $2 \cdot 3$ & $22 \cdot 7$ \\
\hline
\end{tabular}

† Only one plasma progesterone determination.

The plasma progesterone, uterine proteins and uterine progesterone levels in uterine flushings at different stages of pseudopregnancy are shown in Table 1. During the first $2 \frac{1}{2}$ days of pseudopregnancy, plasma progesterone levels rose rapidly. High levels of plasma progesterone were then maintained at least until 12 days, although individual variation was marked. Levels of progesterone and total protein in the flushings also rose rapidly during early pseudopregnancy but appeared to follow the plasma progesterone with high levels occurring between $3 \frac{1}{2}$ and $9 \frac{1}{2}$ days. After this time, despite elevated plasma progesterone levels $(20-30 \mathrm{ng} / \mathrm{ml})$ the progesterone and protein levels in uterine flushings both fell rapidly. The correlation coefficient between protein and progesterone in uterine flushings on the logarithmic scale was $0 \cdot 78(P=<0 \cdot 01)$, whereas that between plasma progesterone and progesterone in uterine flushings was less pronounced at $0.51(P<0 \cdot 02)$. Analysis of the proportion of free-to-bound progesterone in 10 flushings recovered between Days $3 \frac{1}{2}$ and $6 \frac{1}{2}$ of pseudopregnancy revealed that most of the progesterone (mean value $82.4 \%$ ) was in the bound form. Since dilution of the steroid increases the dissociation to free steroid, the binding of progesterone in vivo is almost certainly higher. In these studies the specific protein which binds the progesterone has not yet been determined. Uteroglobin, reported to be the main binding protein in uterine flushing (Beato \& Baier, 1975), constituted $40-60 \%$ of the total protein as calculated from scans of acrylamide electrophoresis gels.

Analysis of uterine flushings for other steroids failed to reveal oestradiol-17 $\beta$ or 17-hydroxyprogesterone at any stage of pseudopregnancy. Plasma levels of 17-hydroxyprogesterone were only detectable before ovulation, and in the later phases of pseudopregnancy when new follicles were presumably maturing.

These preliminary results demonstrate that high levels of progesterone in uterine flushings in 
pseudopregnant animals were observed only in the presence of increased uterine protein, the secretion of which is itself dependent on progesterone action (Arthur \& Daniel, 1972; Rahman, Billiar \& Little, 1975). The progesterone levels of uterine flushings are very high. Allowing for a uterine fluid volume of $0.5 \mathrm{ml}$ and a flushing efficiency of $100 \%$, both generous estimates, the progesterone concentration in uterine fluid would be $138 \mathrm{ng} / \mathrm{ml}$. This value is, however, well below saturation values for the available levels of the known progesterone-binding protein uteroglobin, even on the assumption of one binding site per molecule (Beato \& Baier, 1975). The published values for association constants differ by 2 orders of magnitude $\left(2 \times 10^{6}\right.$ to $\left.5 \times 10^{8} \mathrm{M}^{-1}\right)$ (Urzua et al., 1970; Arthur \& Daniel, 1972; Beato \& Baier, 1975). Using the lowest value of $2 \times 10^{6} \mathrm{M}^{-1}$, it can be calculated from experimental data that approximately $10 \%$ of the progesterone would be bound. Use of higher association constants would elevate this percentage. We found an experimental value of greater than $80 \%$ to be bound, a figure of the same order. It is impossible to exclude the criticism that some progesterone may be released by cellular damage at flushing, a difficulty inherent in any procedure for collecting uterine washings. However, cellular damage is unlikely to account for such major shifts in uterine progesterone. The role of binding protein is not revealed by this study. It might function to prevent the embryotoxic effects of free progesterone (Daniel \& Levy, 1964). Alternatively, the presence of the binding protein in the uterine lumen may indicate that progesterone plays a significant role in embryonic steroidogenesis.

We thank Dr Brian Heap for advice, Sylvia Clutterbuck-Jackson for technical assistance and Janis Ingram-Johnson for secretarial help. The work was supported by a grant to Professor C. R. Austin by the Ford Foundation, and one of us (R.E.F.) wishes to thank the Lucy Cavendish College, Cambridge, for their support with a Calouste Gulbenkien Research Fellowship.

\section{References}

Abraham, G.E., Hopper, K., Tulchinsky, D., SWerdloff, R.S. \& Odell, W.D. (1971) Simultaneous measurement of plasma progesterone, 17 hydroxyprogesterone and oestradiol- $17 \beta$ by radioimmunoassay. Analyt. Letters 4, 325-335.

ArThur, A.T. \& DANiel, J.C., JR (1972) Progesterone regulation of blastokinin production and maintenance of rabbit blastocysts transferred into uteri of castrate recipients. Fert. Steril. 23, 115-122.

ARThur, A.T., Cowan, B.D. \& DANIEL, J.C., JR (1972) Steroid binding to blastokinin. Fert. Steril. 23, 8592.

BATra, S. (1974) A new and improved method for the separation of free from protein-bound progesterone. J. Endocr. 62, 537-543.

BeAto, M. \& BAIER, R. (1975) Binding of progesterone to the proteins of the uterine luminal fluid. Identification of uteroglobin as the binding protein. Biochim. biophys. Acta 392, 346-356.

BEIER, H.M. (1968) A hormone-sensitive endometrial protein in blastocyst development. Biochim. biophys. Acta 160, 239-291.

Challis, J.R. \& Illingworth, D.V. (1970) The identification of progesterone in flushings from the reproductive tract of non-pregnant guinea-pigs. $J$. Reprod. Fert. 22, 583-586.

Daniel, J.C., JR \& LeVY, J.D. (1964) The action of progesterone as a cleavage inhibitor of rabbit ova. J. Reprod. Fert. 7, 323-333.
Dickmann, Z., DeY, S.K. \& GuPTA, J.S. (1975) Steroidogenesis in rabbit preimplantation embryos. Proc. natn. Acad. Sci. U.S.A. 72, 298-300.

EMment, Y.P. \& Collins, W.P. (1972) Radioimmunoassay of oestrone and oestradiol in human plasma. Acta endocr., Copenh. 69, 557-582.

Hilliard, J. \& Eaton, L.W. (1971) Estradiol-17ß, progesterone and $20 \alpha$-hydroxy-pregn-4-en-3-one in rabbit ovarian venous plasma. II. From mating through implantation. Endocrinology 89, 522-527.

Johnson, M.H. (1972) The distribution of a blastokininlike uterine protein studied by immune fluorescence. Fert. Steril. 23, 929-939.

KrISHNAN, R.S. \& DANIEL, J.C. (1967) "Blastokinin" inducer and regulator of blastocyst development in the rabbit uterus. Science, N.Y. 158, 490-492.

LOWRY, O.H., Rosebrough, N.J., FARR, A.L. \& Randall, R.J. (1951) Protein measurement with Folin phenol reagent. J. biol. Chem. 193, 265-276.

Murray, F.A., McGaughey, R.W. \& Yarus, M.J. (1972) Blastokinin: its size and shape and an indication of the existence of sub-units. Fert. Steril. 23, 69-80.

Perry, J.S., Heap, R.B., Burton, R.D. \& Gadsby, J.E. (1976) Endocrinology of the early embryo and its role in the establishment of pregnancy. J. Reprod. Fert., Suppl. 25, (in press).

RahmaN, S.S.U., Billiar, R.B. \& LitTle, B. (1975) Induction of uteroglobin in rabbits by progestogens, 
oestradiol-17 $\beta$ and ACTH. Biol. Reprod. 12, 305-314. Urzua, M.A., Stambaugh, R., Flickinger, G. \& MASTROIANnI, L. (1970) Uterine and oviduct fluid protein patterns in the rabbit before and after ovulation. Fert. Steril. 21, 860-865.

WALTERS, D.E. (1974) The use of asymptotic models in multiple hormone assays. J. Roy. Stat. Soc. C 23, 43-50.

Received 22 July 1975 